\title{
Establishment of Low Cost Homes Using Super Adobe Technology
}

\author{
M. Venkateswarulu ${ }^{1} *$, K. Suresh ${ }^{2}$ and G. Ashok ${ }^{3}$ \\ ${ }^{* 1}$ Associate Professor, \\ ${ }^{2}$ Professor and Head of Department, \\ ${ }^{3} P G$ Student, \\ Department of Civil Engineering, CMR College of Engineering and Technology, Kandlakoya, Medchal Road, \\ Medchal District-Telangana 501401
}

\begin{abstract}
The concern many people have about trying to protect the environment and live in a more ecofriendly manner, there is a growing movement to build houses that are more efficient and better suited to their environment. In part, this means making them more energy efficient, less polluting, and less costly. It can also mean trying to use local materials wherever possible to reduce shipping and to make the house blend better into its surroundings. This is the approach taken by those building super adobe houses, also known as earth bag houses. Super adobe houses are houses that are constructed using earth filled bags that are layered to produce the exterior (and something of the interior) walls. Superadobe is a patented system at the service of humanity. We built up these homes to protect the people from huge injuries even when it collapses during earth quake. Individuals are enabled to build their own homes without the use of heavy equipment, with materials native to the country of use. Flood control, erosion control, and stabilization of water' edges, hillside slopes and embankments, landslides and infrastructures are applications in which super adobe system has shown great potential.
\end{abstract}

Keywords: Adobe, Earth construction, Housing sustainability, appropriate technologies

\section{Introduction}

The people one third of the world live in houses built with earth, and tens of thousands of towns and villages have been raised practically from the ground they are standing on. Today, world consciousness about the use of natural resources and the new perception planet's equilibrium, are leading us into the new millennium of sustainable living. Super adobe is a form of earth bag construction that was developed by Iranian architect Nader Khalili. The technique uses layered long fabric tubes or bags filled with adobe to form a compression structure. The resulting beehive shaped structures employs arches, domes, and vaults to create single and double-curved shells that are strong and aesthetically pleasing. It has received growing interest for the past two decades in the natural building and Sustainability movements. Super adobe (sandbag and barbed wire) technology is a large, long adobe. It is a simple adobe, an instant and flexible line generator. It uses the materials of war for peaceful ends, integrating traditional earth architecture with contemporary global safety requirements. Long or short sandbags are filled with on-site earth and arranged in layers or long coils (compression) with strands of barbed wire placed between them to act as both mortar and reinforcement (tension). Stabilizers such as cement, lime, or asphalt emulsion may be added. This patented and trademarked technology is offered free to the needy of the world, and licensed for commercial use. This is concerned with the use of earth bags as a structural element in buildings formed wholly of earth bags, in a building method known as flexible form rammed earth. This work will attempt to develop a greater understanding of the behaviour of earth bag structures and explore the feasibility and limits of this building method. Currently the main source of knowledge on earth bag structures is from trial and error and past experience. However the development of the concept showed that the possible utilization of the technology or its combination with other building methods is so extensive that may be only our fantasy can set a limit to it.

\section{Methodology}

1. Select a location for your super adobe house that will work for this style of construction. While it is possible to build these houses in colder, wetter climates, it requires much more work, and the house is far less likely to be approved by the building department.

2. It is better to choose a location that is relatively dry. Sketch out on paper your ideas for your house. Remember that super adobe houses are constructed as domes with very thick walls, so large rooms are difficult to achieve. If you want a larger house, it is better to design a series of interconnected domes. 
3. Clear and level the site you will be building on. Place a number of markers in the ground to outline shape of your super adobe house based on the plans you sketched. Run string around these markers to serve as a guide.

4. Fill your bags with soil. You want them to be fully filled so as to avoid shifting or too much settling (although there is always some initial settling in a super adobe house). Place one layer of these bags at the bottom of the trench. Now place two long strips of barbed wired on top of this layer lengthwise along the whole length of the trench.

5. Repeat the same as many times as it takes to create you dome.

6. With each new layer, you want to alter the angle of the layer slightly to form the arch of the dome. Have a reference angle cut in wood that you can hold up against the outside to make sure you are getting it right.

7. Also make sure that you place wooden place holders for things like doors and windows, and plastic tubes for adding plumbing, electrical installations.

8. Add the windows, doors, wiring and pipes. Then seal everything (including the exterior) with a layer of papercrete.

The essential material in building with bags is, of course, the bags themselves. Most commonly the bags used are made of polypropylene or burlap. Polypropylene sacks come in a variety of sizes, and are extremely common. It is important that UV resistant bags be used, as deterioration by sunlight is the biggest danger. Recycled seed or feed sacks of polypropylene are often available for free from various sources. The sacks come in a variety of sizes and also come in a tube form, which is much cheaper to buy per square foot. Burlap sacks have also been used, but are not as durable and can also be more expensive, although they are a "natural" material. Custom-sewn bags have been created for special shapes, and "site sewn" custom bags can easily be made using bent nails or wire The other essential material is that which fills the bag. A number of materials have been used, including sand, clay and gravel. While an ideal mixture would be a standard adobe mix of sand and clay, pretty much whatever subsoil is available is what has been used. The fill material can be used either wet or dry, but moistened material creates a more stable structure. An efficient system is to create your sack foundation and/or walls using soil from site excavation. The most important consideration for bag choice is the material used to fill it. A good rule of thumb is the weaker the fill material, the stronger the bag material must be. In some cases, once a strong fill material has set, the bags could be removed from the exposed areas of the structure without any structural loss of integrity. On the other hand, if a weak material such as dry sand is used, it is essential that the bags be kept integral, and plastered as soon as possible. Additional materials used in construction include barbed wire, used to keep the bags from slipping, and regular wire, which can be used to weave the bags similar to basket-making techniques. For extremely strong structures, cement can be used to create soil-cement mixtures to fill the bags. Old nails are often used to pin bags closed, create new shapes, and keep barbed wire in place. Tools adapted to or developed for this technique are easily available or constructed. A wheelbarrow is used to transport materials and can be used to directly pour soil into larger bags. Stands to hold bags open for filling have been made with a variety of materials.Tube sections of cardboard or PVC which fit into the longer tube-shaped bags and make easier to fill these bags. Mechanical pumps have been used at Cal Earth with great efficiency to fill the tubular bags. A tamper is an essential tool used to compact the bags once they are in place. The best tamper I have used was created from a 5 foot long $11 / 4$ " piece of metal pipe welded to a $6 \times 6$ 1/4" metal plate.Coffee cans filled with soil can be tossed easily and used to fill bags higher up on the wall. Simple forms of wood or metal are used with earth bags to create vaults, while domes are most effectively formed using a simple compass which acts as a placement guide for the bags. An excellent design for such a compass is to attach one end of a lightweight pipe (electrical conduit or an extendable pole used in pool cleaning) to a caster from which the wheel has been removed. This allows for articulation and rotation, and the caster can be easily attached to a $4 \times 4$ piece of wood set in the ground at the center of the dome. On the other end of the pipe, an excellent guide is a piece of "L" shaped metal attached with a pipe clamp. In order to create level rows of bags, a small adjustable level is attached near the guide end of the pipe where a person placing the bags can easily see it. Special compasses to create catenary shaped domes have also been developed. In addition to these guides used to create curved forms, I have used portable metal guide frames which are strung with levelling string to create straight walls.

\section{Estimating Costing}

\section{Fill material}

This is preferably sourced close to or on site, from excavations or surface material. Almost any earth material can be used, providing it is not top soil or other organic rich soil.

The fill material may well not have any cost if site sourced.

\section{Bag filling}

Bags can easily be manually filled, using a simple wooden plate (template for making this can be supplied) and 2 cones. 
The approximate filling rate is 300 bags per team of 2 per day. This is 150 bags per person per day.

Costing of a simple structure

The following estimated costing is as applied to a $9 \mathrm{~m}^{2}(3 \mathrm{~m}(\mathrm{~L}) \times 3 \mathrm{~m}(\mathrm{~W}) \times 2.7 \mathrm{~m}(\mathrm{H}))$ structure. Total wall area is approximately $63.5 \mathrm{~m}^{2}$ including openings.

- $\quad$ excluding design fees

- $\quad$ excluding plumbing and electrical installations and connections

- excluding site clearance

- external walls only, no internal partitions

\section{Cost estimation of materials used:}

\begin{tabular}{|l|l|l|}
\hline Sl.No & Description & Rate \\
\hline 1 & Gravel, sand \& other materials. & Rs. 200/cu m \\
\hline 2 & Labour (per day) & Rs. 250 (per head) \\
\hline 3 & Ventilation pipes (4) & Rs. 100 \\
\hline 4 & Barbed wire & Rs. 7.80/meter \\
\hline 5 & Wooden piece for door & Rs 24(per sq.feet) \\
\hline 6 & Earth bag & Rs. 4.5/bag \\
\hline 7 & Iron frame for support 3 feet $^{\wedge} 1.5 f e e t$ & Rs. 150 \\
\hline
\end{tabular}

\section{Calculations}

Diameter $(D)=$ the width of a circle $=9$ feet

Radius (r) $=$ half the width of the diameter $=4.5$ feet

Circumference $(C)=$ the perimeter length of a circle $=63.61$

$\operatorname{Area}(\mathrm{A})=$ the square footage of a circle $=144$ sq feet

$\operatorname{Pi}()=(3.1416)$

$$
\begin{aligned}
& \bullet \quad \text { Area taken to built a super adobe home } \\
& A=\pi r^{2}=3.141^{\wedge} 6^{\wedge} 6=113.09 \mathrm{sq} \mathrm{ft} \\
& =11.06 \mathrm{sq} \mathrm{m} \\
& \bullet \quad \text { The inner diameter of circle } \\
& A=\pi r^{2}=3.141^{\wedge}\left(4.5^{\wedge} 4.5\right)=63.5 \mathrm{sq} \mathrm{ft} \\
& =6.189 \mathrm{sqm}
\end{aligned}
$$

- Earth work excavation to built:

$\mathrm{A}=$ Outer area vol-inner area vol

$$
=3.18-1.38=1.387 \mathrm{cu} \mathrm{m}
$$

- Total volume of material used for filling of earth bags

- volume of sand used for 3 feet of height

$\mathrm{v}(\mathrm{o})=\pi r^{2} \mathrm{~h}=\pi^{\wedge}\left(1.825^{2}\right)^{\wedge} 0.914$

$=9.537 \mathrm{cu} \mathrm{m}$

$\mathrm{V}(\mathrm{i})=\pi^{\wedge}\left(1.37^{2}\right)^{\wedge} 0.914=5.395$

$\mathrm{V}=9.537-5.395=4.178 \mathrm{cu} \mathrm{m}$

- $\quad$ volume of sand used for 6 feet (hemisphere)

$$
\mathrm{v}(\mathrm{o})=\frac{2}{3} \pi R^{3}=0.67^{\wedge} 3.141^{\wedge}(1.828)^{3}
$$$$
=12.807 \mathrm{cum}
$$

$\mathrm{v}(\mathrm{i})=\frac{2}{3} \pi R^{3}=0.67^{\wedge} 3.141^{\wedge}(1.524)^{3}$

$=7.409 \mathrm{cu} \mathrm{m}$

$\mathrm{V}=12.807-7.409=5.397 \mathrm{cu} \mathrm{m}$

- volume of earth bag used in construction of home

- volume of sand filled in each bag

$\mathrm{v}=\left(0.782^{\wedge} 0.487^{\wedge} 0.15\right)=0.057 \mathrm{cu} \mathrm{m}$

- total number of bags used to build=

(total volume of material used) /(vol of sand filled in each earth bag)

$=(9.567) /(0.057)=170($ aprx $)$

- barbed wire used for construction

$\mathrm{Q}=\left(425^{\wedge} 2\right) / 3.3=257.57=0.257 \mathrm{q}$

- $\quad$ size of the pipes used as ventilators

- $\quad$ size of the door $=1.672 \mathrm{sq} \mathrm{m}$

- $\quad$ Size of the frame $=0.409 \mathrm{sq} \mathrm{m}$

$11.06 \mathrm{sq} \mathrm{m}(12 \mathrm{ft})$
$6.189 \mathrm{sq} \mathrm{m}(9 \mathrm{ft})$
$1.387 / \mathrm{cu} \mathrm{m}$.
$9.567 / \mathrm{cu} \mathrm{m}$.
$4.1178 / \mathrm{cu} \mathrm{m}$.

$5.397 / \mathrm{cu} \mathrm{m}$
$0.257 \mathrm{q}$
no's 4
$6 \mathrm{ft} 1.5 \mathrm{ft}$
$3 \mathrm{feet}$
$0.057 / \mathrm{cu} \mathrm{m}$.
No's 170
$\mathrm{~m}\left(0.782^{\wedge} 0.487 \wedge 0.15\right)$

International Conference on Recent Innovations in Civil \& Mechanical Engineering [i- CAM2K16] DOI: 10.9790/1684-16053018083 
To calculate, how many bags will we need for this construction?

- Convert bag height and length into feet.

Total number of bags used to build=

(Total volume of material used) / (vol of sand filled ineach earth bag)

$=(9.567) /(0.057)=170($ aprx $)$

Height of home: $18 \div .0 .6 \mathrm{ft} .(15.24 \mathrm{~cm}) / \mathrm{bag}=9 \mathrm{ft} .(2.7 \mathrm{~m})$

Length of each row: $3 \mathrm{ft} .(2.7 \mathrm{~m}) \div 0.6 \mathrm{ft}$. $(15.24 \mathrm{~cm}) / \mathrm{bag}=18$ bags per row.

Analysis of Rates

\begin{tabular}{|l|l|l|l|l|l|}
\hline Sl.No & Particulars & Quantity & Units & Rate & Cost \\
\hline 1 & Sand, gravel and other material & 9.567 & Cum & 125.43 & 1200 \\
\hline 2 & Workmen & & & & \\
\hline & Skilled workmen & 1 & Man days & 250 & 250 \\
\hline & Unskilled workmen & 3 & Man days & 250 & 750 \\
\hline 3 & Ventilators ( Stoneware Pipes ) & 4 & Units & 25 & 100 \\
\hline 4 & Barbed wire & 25.7 & Kg & 5.7 & 1482 \\
\hline 5 & Wooden door & & & 432 \\
\hline 6 & Plastering with soil & 2 & Cum & 235 & 470 \\
\hline 7 & Earth Bags & 170 & No's & 4.5 & 765 \\
\hline 8 & Iron frame for lintel support (lumsum) & 1 & & & 150 \\
\hline 9 & Overhead costs (lumsum) & & & 500 \\
\hline & & & & & \\
\hline
\end{tabular}

\section{Conclusion}

Super adobe is a Building technique that uses long fabric tubes filled with an inorganic material using locally available, minimally processed natural materials is the logical solution. There is simply no other way to create affordable housing for all those in need that Using dirt-cheap building materials earth, sand, gravel, straw, recycled materials, etc. layered on top of each other with barbwire in between the layers to provide friction and avoid sliding off. The layers go up and build a beehive-like shape with arches, domes and vaults that are structurally strong and aesthetically very pleasing and eliminating expensive contractors and specialized equipment, the cost of construction can be slashed to a fraction of conventional housing costs. The uses of Super adobe to built family houses, semi-detached and terraced house, small block of flats, subdivisions, ecovillages, holiday houses, bungalows, camps, garages etc. Time taken for completion of super adobe structure is 2 days. Cost we incurred on constructing super adobe structure is 6099/-. When compared to conventional RCC house it is less expensive where it costs around 70000/-. Benefits of Super adobe are that it has high resistance towards earthquakes, floods, wind blows etc. So we expect that the proposed technology is useful for the development of structures at a very low cost. Everyone needs a place to live - shelter is a basic need. But since the current system is bypassing the vast majority of the population, it's time to turn to simpler, more affordable building methods.

\section{Acknowledgements}

The authors express gratitude to the Head, Department of Civil Engineering CMR College of Engineering and Technology, Kandlakoya Medchal road Medchal district for providing necessary Laboratory facilities.

\section{References}

[1] California Institute of Earth Art and Architecture (Cal-Earth) in the year 1971.

[2] Allen, Edward. Stone Shelters. MIT Press, 1981.

[3] Bee, Becky. The Cob Builder's Handbook. Groundwork's, 1997.

[4] Boily, Lise and Jean-Francis Blanchette. The Bread Ovens of Quebec. National Museums of Canada, 1979.

[5] Bourgeois, Jean-Louis and Carol Lee Pelos. Spectacular Vernacular. Aperture Foundation, 1996.

[6] Chiras, Daniel D. The Natural House. Chelsea Green Publishing, 2000.

[7] Courtney-Clarke, Margaret. African Canvas. Rizzoli, 1990. (West African women's stunning vernacular art and

[8] architecture)

[9] Easton, David. The Rammed Earth House. Chelsea Green Publishing, 1996.

[10] Elizabeth, Lynne and Cassandra Adams. Alternative Construction. John Wiley and Sons, 2000.

[11] Evans, Ianto, Linda Smiley, and Michael Smith. The Hand Sculpted House. Chelsea Green Publishing, 2002.

[12] Ferguson, William M. and Arthur H.Rohn. Anasazi Ruins of the Southwest in Colour. University of New Mexico Press, 1994

[13] Gray, Virginia, Alan Macrae, and Wayne McCall. Mud, Space, and Spirit. Capra Press, 1976. 